\title{
Effects of Fintech on Stock Return: Evidence from Retail Banks Listed in Indonesia Stock Exchange*
}

\author{
Saraya Cita ASMARANI', Chandra WIJAYA ${ }^{2}$
}

Received: May 16, 2020 Revised: May 24, 2020 Accepted: June 07, 2020

\begin{abstract}
This study examines the effect of fintech on retail banks stock return listed in Indonesia Stock Exchange for the period of 2016-2018 as today's new technology lead to the emergence of fintech companies playing the same role as retail banks in the financial industry. This study is conducted quantitatively using monthly data from January 2016 to October 2018 and uses fintech as independent variable, proxied by fintech funding frequency and fintech funding value. Data transformation is conducted due to data volatility. The data of fintech funding, both frequency and value, is transformed into standardized fintech funding and growth of fintech funding. The data is obtained from Crunchbase, while the data of stock returns is obtained from Investing. This study further analyzes the data using Fama French Three-Factor Model and panel data regression. We found that fintech has no significant effect on retail banks' stock returns listed in Indonesia Stock Exchange for the period of 2016-2018. The findings of the study provide some useful insights in understanding fintech companies' current position to retail banks in Indonesia. This study also suggests banking institutions, fintech companies, policy-makers, and others to take advantageous steps in building inclusive financial sectors.
\end{abstract}

Keywords : Fintech, Retail Banks, Stock Return, Fama French Three-Factor, Panel Data

JEL Classification Code: G20, G21, O16

\section{Introduction}

Retail banks are banks providing various financial services to individual consumers and small businesses (Omarini, 2015). In accordance with its definition, according to Omarini (2015), retail banks act as financial institutions

\footnotetext{
*Acknowledgements:

We thank Research Cluster of Governance and Competitiveness, Faculty of Administrative Science, Universitas Indonesia for providing supporting materials regarding discussions and assisting us in writing this manuscript.

${ }^{1}$ First Author. Department of Business Administration, Faculty of Administrative Science, Universitas Indonesia, Indonesia. Email: saraya.cita@ui.ac.id

${ }^{2}$ Corresponding Author. Professor, Department of Business Administration, Faculty of Administrative Science, Universitas Indonesia, Indonesia [Postal Address: Kampus UI, Depok 16424, Jawa Barat, Indonesia] Email: wijaya@ui.ac.id

(c) Copyright: The Author(s)

This is an Open Access article distributed under the terms of the Creative Commons Attribution Non-Commercial License (http://Creativecommons.org/licenses/by-nc/4.0/) which permits unrestricted noncommercial use, distribution, and reproduction in any medium, provided the original work is properly cited.
}

and financial intermediaries in which they take deposits from customers and channel loans, and act as supporters of economic development as they facilitate trade by operating payment systems and becoming the main source credit for most businesses. Traditionally, the retail banking industry ran its business with customers through face-to-face interactions. However, along with the development of technology, retail banks play their roles in digital banking to offer products and services to customers (Capgemini \& Efma, 2016).

According to KPMG (2017), digital banking ranks first in retail bank attributes that are considered important by the retail bank industry such as administrative costs, ATM machine locations, and others. EY, in their Global Banking Outlook 2018, stated that around $82 \%$ of retail banks in the world seek efficiency through the adoption of technology for digital banking. In addition, it was stated that $85 \%$ of retail banks in the world sought to implement digital transformation as a top priority in 2018 , and $89 \%$ of them sought to tighten cyber and data security. According to a survey conducted by PwC (2018) of banks in Indonesia, 66\% have made digital strategy a corporate strategy. Meanwhile, $12 \%$ of them made digital banking as an IT strategy, followed by $16 \%$ who made digital strategy as a product strategy and customer strategy, 
4\% making a digital strategy as an integral digital strategy, and $2 \%$ as an operating strategy.

At the end of 2015, Sorrentino in Forbes (2015) stated that the banking industry will come through changes with the emergence of fintech, the increasing popularity of new technologies such as blockchain, artificial intelligence, and the dominance of millennials. Fintech companies, as providers of financial services based on digital technology, revolutionize how financial services are carried out with increased comfort and lower operating costs as key drivers (Buckley, Arner, \& Barberis, 2015; Chuen, Lee, \& Teo, 2015). In regard to technological development, transactions in the field of personal loans, payments, savings, and others are no longer played solely by retail banks. Fintech companies also play an important role in offering financial service products especially in consumer banking (Chishti \& Barberis, 2016).

According to Dean and Gigilierano (1990) and Mina, Lahr, and Hughes (2013), external funding can be a relevant and credible measurement in looking at future growth in startups. It is also stated by Deloitte Center for Financial Industry (2017) that the amount and timing of investment in fintech companies can be an important indicator of startup viability. Looking at global external funding activities in fintech companies, fintech companies and their development are to increase. As reported by KPMG (2018), global fintech investment advanced at a record pace in the first six months of 2018, with a value of 57.9 billion US dollars invested in 875 transactions, a significant increase of $\$ 38.1$ billion as invested in 2017.

Indonesia has 262 fintech companies, with or without license, and takes place as the country with the secondlargest number of fintech companies in ASEAN after Singapore (EY FSO ASEAN Study, 2018). Based on the statistics from Bank Indonesia (2018), the value of fintech transaction was 15.02 billion US dollars or 202.77 trillion rupiah in 2016 . The transaction value increased by $24.71 \%$ to 18.65 billion US dollars or amounting to 251.78 trillion rupiah at the end of the year 2017 (Rita, 2018). The fintech lending industry has dispensed funding to MSMEs as much as 2.56 trillion rupiah in 2016 and has increased by $173.4 \%$ with an amount of 7 trillion rupiah in June 2018. This growth illustrates the role of fintech lending in supporting UMKM funding (Muradi, 2018).

According to EY, $40 \%$ of retail bank customers in the world have reduced their dependence on retail banks due to the emergence of fintech companies. The development of fintech companies caused retail banks to look for ways to maintain their position in the financial industry. Most retail banks in the world chose to partner with fintech companies.

In Indonesia, some of the retail banks have started working and collaborating with fintech companies. The Financial Services Authority (OJK) also encouraged fintech companies and retail banks to collaborate to accelerate financial inclusion and open access to finance for the wider community (Agustiyanti, 2016). For example, Bank Central Asia (BCA) launched Central Capital Ventura, a venture capital company formed with BCA Finance. This company will invest in fintech companies in Indonesia. In addition, BCA also cooperates with fintech KlikAcc in lending services to MSMEs (Rahmah, 2018). Bank Mandiri also cooperates with KoinWorks and Amartha in lending to MSMEs. Bank Mandiri does this with the aim of reaching a wider market (Bahri, 2018).

According to Li, Spigt, and Swinkels (2017), the emergence of fintech companies in financial industry, especially retail or consumer banking, evokes three theories that illustrate the influence of fintech on retail banks as incumbents. The first theory is a theory that illustrates that fintech will give a substitution effect on retail banks, which is a negative influence on retail banks due to their disruptive characteristic. Secondly, according to Romānova and Kudinska (2016), fintech can have a positive effect or complementary effect on retail banks through cooperation with low operational costs, wider customer reach, and not geographically concentrated. The third theory is the theory stating that the emergence of fintech has no influence on retail banks because fintech companies are still relatively small to give effect to retail banks as incumbents.

Sahi (2017), in his thesis, examined market reactions to announcements of listed companies' acquisition of fintech companies, and market reactions to IPO activities carried out by fintech companies. Sahi (2017) examined this by looking at announcements or announcements of fintech acquisition conducted by public companies and their influence on market returns, as well as looking at the IPO performance of fintech companies. The results showed that there was a positive reaction on the market in the announcement of open company acquisition of fintech companies and market reaction to fintech conducting IPOs.

As stated by Miller and Liu (2014) and Sood and Tellis (2009), the possibility of future disruptive pressures can suppress incumbents' stock price, so we choose to use stock returns as variable to see stock prices movements. According to Dean and Gigilierano (1990), Davila, Foster, and Gupta (2003), and Mina, Lahr, and Hughes (2013), external funding can be a relevant and credible measurement in looking at future growth in startups. Li, Spigt, and Swinkels (2017) analyzed the effect of fintech on retail banking by looking at the frequency and value of fintech funding and its effect on stock returns in 47 retail banks in the United States. These are what prompted us to conduct the study by using the value and frequency of fintech funding as proxies to see the effect of fintech on retail bank stock returns with a span of 34 months, from January 2016 to October 2018. 


\section{Literature Review and Hypothesis Development}

\subsection{The Role of Retail Banks}

Retail banks are banks providing various financial services to individual consumers and small businesses (Omarini, 2015). Retail banks act as financial institutions and financial intermediaries in which they take deposits from customers and channel loans to borrowers who meet the requirements. Retail banks also have roles as payment and money transfer system providers. In addition, retail banks also have the ability to provide information about investment, insurance, and other financial matters (Navaretti, Calzolari, \& Pozzolo, 2017).

According to Omarini (2015), retail banks play an important role in serving customers by facilitating payment services. Over time, the retail chain of bank services has become more diversified, from checks to transfers, from debit cards to credit cards and digital wallets. In addition, in-depth knowledge of data and how to analyze it are increasingly prioritized in organizations in the financial industry. The development of technology also brings the development of data analysis methods, ranging from web analysis to digital analysis, thus encouraging the emergence of digital banking.

\subsection{The Emergence of Fintech Companies}

The use of technology in digital banking in service innovation is to produce banking products and services to meet customer needs (Mbama, 2018). Products and services offered in digital banking can be in the form of money transfers, account management, paying bills, payment systems, and others. Digital banking via the Internet and cellular phones has become the main way of delivering services to customers, which is a challenge for the traditional banking model (Mbama, 2018).

According to Lee and Shin (2017), fintech is one of the many significant innovations in the financial industry and continues to evolve rapidly, driving the economy, driven by information, technology, and regulation. Fintech is defined as the use of technology in delivering financial solutions. Deloitte Center for Financial Services (2017) defined fintech as small technology-based startup companies that either provide financial services to the marketplace or primarily serve the financial services industry. Fintech is now seen as a unique "marriage" between financial services and information technology (Buckley, Arner, \& Barberis, 2015). According to Bank Indonesia regulations regarding financial technology or fintech, fintech is the use of technology in the financial system that produces new products, services, technology and/or business models and can have an impact on monetary stability, financial system stability, and/ or efficiency, smoothness, security and reliability of the payment system (EY Indonesia, 2018). Fintech refers to new processes and products available for financial services resulted from the advancement of digital technology (Navaretti, Calzolari, \& Pozzolo (2017). According to Huang (2015), fintech is a company that uses technology for banking, payment, financial data analysis, capital markets, and personal financial management. The Financial Stability Board (2017) defines fintech as a technological innovation that can produce new business models, applications, processes, and products in financial services.

Lee and Shin (2017) identified six types of fintech, namely, payment, wealth management, crowd-funding, lending, capital markets, and insurance services. Bank Indonesia classified fintech into four major categories, namely, crowdf-unding and peer-to-peer lending; market aggregator; investment management; and payment, settlement, and clearing. Referring to the large category classified by Bank Indonesia, EY Indonesia (2018) divided fintech into four major categories with several subcategories below. EY Indonesia (2018) classified fintech into four categories which are lending consisting of pool lending, peer-to-peer, crowd-funding, and pawnbrokers; payment and supports consisting of point-of-sales, payment gateway, e-wallet, enabler, and remittance; aggregator consisting of multi-products aggregator, credits aggregator, and insurance services; and financial planning consisting of forum, mutual funds, and commodities.

Deloitte Center for Financial Services (2017) segmented fintech into four major categories that are banking and capital markets, investment management, insurance, and real estate. The banking and capital markets category is divided into five subcategories, namely, banking operations, deposits \& lending, capital raising, financial management, and payment. The investment management category is divided into five subcategories, namely financial research and data, institutional investing, and retail investing. The insurance category is divided into five subcategories, namely commercial insurance, customer acquisition insurance, insurance operations, $\mathrm{P} 2 \mathrm{P}$ insurance, and personal insurance. The last category is real-estate, divided into three subcategories, namely, financing and investing, leasing and P\&S transactions, and property development and management.

Li, Spigt, and Swinkels (2017) conducted a study on the effect of fintech on retail banks in the United States, in this case looking at the stock price based on the theory put forward by Miller and Liu (2014) and Sood and Tellis (2009) that the possibility of future disruptive pressures can suppress incumbents' stock price. The method used in this study is a quantitative method with a data panel regression model and 
the Fama French Three-Factor. The variables used in this study are fintech funding as independent variables and retail banks stock returns as dependent variables. This study uses fintech funding frequency and value as proxies. The results showed that there was no effect of fintech funding on retail bank stock returns in the period of 2010-2016 in the United States.

Sahi (2017) wrote a study with the title of "Studying market reactions to technology companies - Acquisitions and initial public offerings in OECD Countries". The purpose of this study is to explain the market reaction to fintech by examining the underpricing of these companies after going public and the short-term shocks created by the announcement of fintech acquisition regarding the price of shares of the acquiring company. The results showed that there was a positive abnormal return one day after the announcement of fintech acquisition carried out by the acquiring company. In addition, for the case of the Fintech IPO, after measuring whether the Fintech hype had an impact on underpricing the IPO, the results showed that fintech companies experienced significant underpricing.

According to Dickerson et al. (2015), investment in global fintech grew by $75 \%$ and is expected to continue to increase. The development of fintech according to $\mathrm{Li}$, Spigt, and Swinkels (2017) evokes three theories regarding the effect on retail banks. The first theory is an optimistic theory seeing fintech devouring or undermining retail banks and be the substitution of retail banks, thus negatively influencing retail banks' shares prices when the fintech industry is experiencing growth. Fintech, which offers successful substitutions for traditional financial services, can disrupt the retail banking industry $(\mathrm{Li}$, Spigt, \& Swinkels, 2017). According to this theory, innovative newcomers can eventually replace incumbents, or companies that have been established for a long time. Fintech companies can trigger a disruptive evolution due to their new alternatives they offer in improving service efficiency and quality (Ferrari, 2016). Improvement for efficiency is predominantly attributable to loan personalization and disintermediation processes by eradicating intermediaries, which significantly reduces transaction costs for consumers (PwC, 2016). New technologies, such as cognitive cloud computing and blockchain, can also increase efficiency (Peters \& Panayi, 2015; Wood \& Buchanan, 2015). This innovation will give advantage fintech companies as banks generally rely on technological infrastructure that is decades old (Laven \& Bruggink, 2016). In addition, according to Hannan and McDowell's study conducted in 1984, banks generally tend not to adopt new technology quickly due to regulatory matters.

The second theory was put forward by Jun and Yeo (2016) that fintech will positively affect retail banks by providing complementary effects. Fintech will complement retail banking services as many retail banks have noticed the significance of fintech and are trying to incorporate the technology into their business, whether through collaboration, outsourcing services, funding, or acquisition. Fintech is more visible in favor of retail banks than disrupting ( $\mathrm{PwC}, 2016)$. In addition, collaboration between banks and fintech also benefits small players. By collaborating with banks, fintech companies can gain access to the global payment system and retail bank customers. This also reduces the barriers of fintech companies entering the financial industry and allows fintech to gain more trust from the public (Juengerkes, 2016).

The third theory developed by Sorkin (2016) explains that retail banks are too big and too strong to be influenced by fintech, so fintech does not affect retail banks and their share prices. If it does not produce effect, it can be said that fintech companies serve a new channel because fintech companies attract customers who are not served by retail banking services or underbanked. For example, small companies at risk, consumers with less credit history, or loans that are not too large in number (Demos, 2016; Hayashi, 2016). Fintech companies utilize technology to estimate the creditworthiness of these borrowers more easily and cheaply (Hayashi, 2016). Not giving influence can also show that fintech companies as a newly established are still too tiny in size compared to retail banks as these incumbents handle transactions with the value of trillions.

According to Navaretti, Calzolari, and Pozzolo (2017), fintech offers services similar to retail banks, with the possibility of being more efficient because of the technology they acquire, but in different ways. For example, like banks, crowd-funding platforms convert savings into loans and investments. However, it is different from banks because the information used is based on big data where access to services is only through the Internet, not the long-term relationships of customers and banks. In crowd-funding activities or peer to peer lending, borrowers and lenders can be connected directly, so disintermediation is induced. In addition, fintech also provides payment services where these services are still supported by retail banks. Retail banks may lose a little of their profits, but the payment system by fintech is still done with top-ups through one retail bank.

Based on research conducted by Li, Spigt, and Swinkels (2017), fintech has no effect on retail bank stock returns in the United States from 2010 to 2016 . We refer to the thinking framework of research journals conducted by Li, Spigt, and Swinkels (2017), which helps generate the following hypotheses in this study:

H0: There is no effect on fintech funding frequency on retail banks stock returns listed in Indonesia Stock Exchange

H1: There is an effect on fintech funding frequency on retail banks stock returns listed in Indonesia Stock Exchange 
H0: There is no effect on fintech funding value on retail banks stock returns listed in Indonesia Stock Exchange

H1: There is an effect on fintech funding value on retail banks stock returns listed in Indonesia Stock Exchange

\section{Methodology}

This study examines the effect of fintech, in this case fintech funding, on the returns of retail bank stocks listed in the Indonesia Stock Exchange with selected retail bank based on the criteria. This study examines fintech companies with categories of payment or payment, loans or lending along with crowd-funding in it, personal finance, and market aggregator. The fintech categories examined are categories that have similar roles to retail banks, namely providing consumer banking services and products. To examine the object of stock returns or returns on retail banks, this study uses monthly data from fintech funding and stock returns.

This study uses quantitative approaches. This study is a panel study as it uses panel data regression methods with a total sample of eight companies each month or 272 observations for the 2016-2018 period. This study uses a purposive sampling technique in which the criteria for the sample were determined beforehand. The purposive sampling technique is conducted to select retail banks that reacted to the emergence and development of fintech in Indonesia. The criteria for purposive sampling are as follows:

1. Banks have been listed on the Indonesia Stock Exchange (IDX) before the research period, namely January 1, 2016.

2. The bank is not delisted from the Indonesia Stock Exchange (IDX) during the period of 1 January 2016-31 October 2018.

3. The bank has cooperated with or collaborated with one or more fintech companies, and or injected funds into one or more fintech companies during the period of January 1, 2016-31 October 2018.

4. The bank has all the data needed for predetermined variables.

This study obtained data from the Crunchbase site for fintech-funding data and Investing for stock returns data. After conducting several tests, the best regression estimation model to use is the Random Effect Model.

The period of data taken in this study is the data for 2016-2018, seeing the availability of data given that fintech is a relatively new thing in Indonesia. In addition, in 2011 to 2012, fintech growth was only 6\% (Fintech Actors, 2017). Then, in 2013 to 2014, fintech growth rose to $9 \%$. However, this growth experienced a very significant increase in 2015 to 2016 , which was to be $78 \%$. Looking at the data, in 2014 to 2015 there was still very little funding for fintech in Indonesia. However, starting from 2015, funding for fintech began to take place. This study aims to determine the effect of the value and frequency of fintech funding on the returns on retail bank shares listed in the Indonesia Stock Exchange for the period of 2016-2018.

In this study, we examine the effect of fintech on the retail banks stock returns listed in the Indonesia Stock Exchange for the period of 2016-2018. Fintech as an independent variable is proxied as fintech funding where fintech funding is seen from its frequency and value. Since fintech funding data is volatile from month to month, data transformation is carried out. Fintech funding frequency data is transformed into standardized fintech funding frequency and growth of fintech funding frequency. Similarly, the value of fintech funding is transformed into the standardized fintech funding value and the growth of fintech funding values. Funding value and frequency data will be transformed and calculated using the following formula:

1. Standardized Fintech Funding Value:

$$
z t=(x t-\bar{x}) / s, \mathrm{t}=1,2, \ldots, \mathrm{n}
$$

Where:

$z t=$ Standardized fintech funding value

$x t=$ Fintech funding value of month $\mathrm{t}$

$\bar{x}=$ The average of fintech funding value

$s=$ Standard deviation

2. Fintech Funding Value Growth:

$$
g t=\ln x t-\ln x t-1, \mathrm{t}=2,3, \ldots, \mathrm{n}
$$

Where:

$g t=$ Fintech funding value growth

ln = Natural logarithm

$x t=$ Fintech funding value of month $\mathrm{t}$

$x t-1=$ Previous fintech funding value of month $\mathrm{t}$

3. Standardized Fintech Funding Frequency:

$$
z t=(x t-\bar{x}) / s, \mathrm{t}=1,2, \ldots, \mathrm{n}
$$

Where:

$z t=$ Standardized fintech funding frequency

$x t=$ Fintech funding frequency of month $\mathrm{t}$

$\bar{x}=$ The average of fintech funding frequency

$s=$ Standard deviation 
4. Fintech Funding Frequency Growth:

$$
g t=\ln x t-\ln x t-1, \mathrm{t}=2,3, \ldots, \mathrm{n}
$$

Where:

$g t=$ Fintech funding frequency growth

$\ln =$ Natural logarithm

$x t=$ Fintech funding frequency of month $\mathrm{t}$

$x t-1=$ Previous fintech funding frequency of month $\mathrm{t}$

The regression model used in this study refers to research journals Li, Spigt, \& Swinkels (2017), namely the Fama French Three-Factor model to see the effect of fintech, which is proxied as fintech funding, on retail banks stock returns listed in the Stock Exchange Indonesia for the 20162018 period. The models are as follows:

$$
\begin{aligned}
R i, t-R f, t & =a i+b i[R M, t-R f, t]+\operatorname{siSMBt} \\
& +h i H M L+\gamma i F i n t e c h S F R t+\varepsilon i, t
\end{aligned}
$$

Where:

$$
\begin{array}{ll}
R i, t & =\text { Stock return of } \mathrm{i} \text { of month } \mathrm{t} \\
R f, t & =\text { Risk free rate of month } \mathrm{t} \\
R M, t & =\text { Market return of month } \mathrm{t} \\
S M B t & =\text { Small Minus Big of month } \mathrm{t} \\
H M L & =\text { High Minus Low of month } \mathrm{t}
\end{array}
$$

Fintecht $=$ Standardized fintech funding frequency

$$
\begin{aligned}
R i, t-R f, t & =a i+b i[R M, t-R f, t]+s i S M B t \\
& +h i H M L+\gamma i \text { FintechGRFt }+\varepsilon i, t
\end{aligned}
$$

Where:

$$
\begin{aligned}
& R i, t=\text { Stock return of } \mathrm{i} \text { of month } \mathrm{t} \\
& R f, t=\text { Risk free rate of month } \mathrm{t} \\
& R M, t=\text { Market return of month } \mathrm{t} \\
& \text { SMBt }=\text { Small Minus Big of month } \mathrm{t} \\
& \text { HML }=\text { High Minus Low of month } \mathrm{t} \\
& \text { FintechGRFt }=\text { Fintech funding frequency growth } \\
& R i, t-R f, t=a i+b i[R M, t-R f, t]+s i S M B t \\
& +h i H M L+\gamma i \text { FintechSVLt }+\varepsilon i, t
\end{aligned}
$$

Where:

$$
\begin{array}{ll}
R i, t & =\text { Stock return of } \mathrm{i} \text { of month } \mathrm{t} \\
R f, t & =\text { Risk free rate of month } \mathrm{t}
\end{array}
$$

$$
\begin{array}{ll}
R M, t & =\text { Market return of month } \mathrm{t} \\
S M B t & =\text { Small Minus Big of month } \mathrm{t} \\
H M L & =\text { High Minus Low of month } \mathrm{t}
\end{array}
$$

FintechtSVL $=$ Standardized Fintech Funding Value

$$
\begin{aligned}
R i, t-R f, t & =a i+b i[R M, t-R f, t]+s i S M B t \\
& +h i H M L+\gamma i \text { Fintech } G R V t+\varepsilon i, t
\end{aligned}
$$

Where:

$$
\begin{array}{ll}
R i, t & =\text { Stock return of } \mathrm{i} \text { of month } \mathrm{t} \\
R f, t & =\text { Risk free rate of month } \mathrm{t} \\
R M, t & =\text { Market return of month } \mathrm{t} \\
S M B t & =\text { Small Minus Big of month } \mathrm{t} \\
H M L & =\text { High Minus Low of month } \mathrm{t}
\end{array}
$$

FintechGRVt $=$ Fintech funding value growth

The first and second models are used to examine the effect of fintech funding frequency on retail banks stock returns. Meanwhile, the third and fourth models are used to see the effect of the fintech funding value on retail banks stock returns.

\section{Results}

The results in Table 1 indicate that the Standardized Fintech Funding Frequency variable represented by ST FREQ has a probability of 0.4783 indicating that there is no significant effect on excess return. Table 2 shows the results that the Fintech Funding Frequency Growth variable, which is represented by GR_FREQ, has a probability of 0.9725 indicating that there is no effect on excess return. The results in Table 3 indicate that the Standardized Fintech Funding Value represented by ST_VALUE has a probability of 0.5537, which implies that there is no effect on excess return. Table 4 shows the results that the Fintech Funding Value Growth variable, which is represented by GR Value, has a probability of 0.3970 , which marks that there is no significant relationship to excess return.

\section{Discussion}

Based on the results, it can be concluded that fintech funding frequency has no effect on retail banks' stock returns. Fintech funding value appears to have the same results with no effect on the stock returns of retail banks. These results show that fintech funding has no effect on the returns of retail banks shares both in terms of value and frequency, thus indicating that fintech has no effect on the stock returns of retail bank shares listed in the Indonesia Stock Exchange yet 
Table 1: Results of Regression Model 1

\begin{tabular}{|c|c|c|c|c|}
\hline \multicolumn{5}{|c|}{ Dependent Variable: RIT_RF } \\
\hline \multicolumn{5}{|c|}{ Method: Panel EGLS (Cross-section random effects) } \\
\hline \multicolumn{5}{|l|}{ Periods included: 34} \\
\hline \multicolumn{5}{|c|}{ Cross-sections included: 8} \\
\hline \multicolumn{5}{|c|}{ Total panel (balanced) observations: 272} \\
\hline Variable & Coefficient & Std. Error & t-Statistic & Prob. \\
\hline $\mathrm{C}$ & 0.007651 & 0.013884 & 0.551065 & 0.5821 \\
\hline RM_RF & 1.059795 & 0.273521 & 3.874645 & $0.0001^{*}$ \\
\hline SMB & 0.354966 & 0.233717 & 1.518786 & 0.1300 \\
\hline HML & 0.194161 & 0.080031 & 2.426071 & $0.0159^{*}$ \\
\hline ST FREQUENCY & -0.004045 & 0.005698 & -0.709962 & 0.4783 \\
\hline
\end{tabular}

* denotes statistical significance at the $5 \%$ level

Table 2: Results of Regression Model 2

\begin{tabular}{|c|c|c|c|c|}
\hline \multicolumn{5}{|c|}{ Dependent Variable: RIT_RF } \\
\hline \multicolumn{5}{|c|}{ Method: Panel EGLS (Cross-section random effects) } \\
\hline \multicolumn{5}{|l|}{ Periods included: 34} \\
\hline \multicolumn{5}{|c|}{ Cross-sections included: 8} \\
\hline \multicolumn{5}{|c|}{ Total panel (balanced) observations: 272} \\
\hline Variable & Coefficient & Std. Error & t-Statistic & Prob. \\
\hline $\mathrm{C}$ & 0.008008 & 0.013993 & 0.572315 & 0.5676 \\
\hline RM_RF & 1.065000 & 0.275294 & 3.868592 & $0.0001^{*}$ \\
\hline SMB & 0.310098 & 0.231741 & 1.338122 & 0.1820 \\
\hline $\mathrm{HML}$ & 0.196745 & 0.080038 & 2.458155 & $0.0146^{*}$ \\
\hline GR_FREQUENCY & -0.000125 & 0.003636 & -0.034475 & 0.9725 \\
\hline
\end{tabular}

* denotes statistical significance at the $5 \%$ level

Table 3: Results of Regression Model 3

\begin{tabular}{|c|c|c|c|c|}
\hline \multicolumn{5}{|c|}{ Dependent Variable: RIT_RF } \\
\hline \multicolumn{5}{|c|}{ Method: Panel EGLS (Cross-section random effects) } \\
\hline \multicolumn{5}{|c|}{ Periods included: 34} \\
\hline \multicolumn{5}{|c|}{ Cross-sections included: 8} \\
\hline \multicolumn{5}{|c|}{ Total panel (balanced) observations: 272} \\
\hline Variable & Coefficient & Std. Error & t-Statistic & Prob. \\
\hline $\mathrm{C}$ & 0.008414 & 0.013904 & 0.605158 & 0.5456 \\
\hline RM_RF & 1.075472 & 0.274222 & 3.921902 & $0.0001^{*}$ \\
\hline SMB & 0.319813 & 0.226162 & 1.414091 & 0.1585 \\
\hline HML & 0.197344 & 0.079974 & 2.467618 & $0.0142^{*}$ \\
\hline ST_VALUE & 0.003219 & 0.005429 & 0.592949 & 0.5537 \\
\hline
\end{tabular}

${ }^{*}$ denotes statistical significance at the $5 \%$ level 
Table 4: Results of Regression Model 4

\begin{tabular}{|c|c|c|c|c|}
\hline \multicolumn{5}{|c|}{ Dependent Variable: RIT_RF } \\
\hline \multicolumn{5}{|c|}{ Method: Panel EGLS (Cross-section random effects) } \\
\hline \multicolumn{5}{|c|}{ Periods included: 34} \\
\hline \multicolumn{5}{|c|}{ Cross-sections included: 8} \\
\hline \multicolumn{5}{|c|}{ Total panel (balanced) observations: 272} \\
\hline Variable & Coefficient & Std. Error & t-Statistic & Prob. \\
\hline C & 0.006697 & 0.013950 & 0.480066 & 0.6316 \\
\hline RM_RF & 1.025290 & 0.277124 & 3.699759 & $0.0003^{*}$ \\
\hline SMB & 0.261798 & 0.233201 & 1.122626 & 0.2626 \\
\hline $\mathrm{HML}$ & 0.208914 & 0.081178 & 2.573536 & $0.0106^{*}$ \\
\hline GR_VALUE & -0.000428 & 0.000505 & -0.848345 & 0.3970 \\
\hline
\end{tabular}

* denotes statistical significance at the $5 \%$ level

for the 2016-2018 period. One of the theories proposed by $\mathrm{Li}$, Spigt, and Swinkels (2017) stated that, if fintech is found not to affect retail banks' shares, fintech companies as newly established in the financial industry still has a small position compared to retail banks as the transactions are still small in size.

Fintech transactions in Indonesia are experiencing very rapid growth. In 2016, based on statistics from Bank Indonesia (2018), the value of fintech transactions was 15.02 billion US dollars or 202.77 trillion rupiahs. The transaction value increased by $24.71 \%$ to 18.65 billion US dollars or 251.78 trillion rupiah at the end of 2017 (Rita, 2018). Especially for the fintech lending industry, this category of fintech has channeled funding to MSME players as much as 2.56 trillion rupiah in 2016 and has increased by $173.4 \%$ with a total of 7 trillion rupiah in June 2018. At the end of 2018, the number of channeled MSME players through fintech lending were IDR 25 trillion. This rapid growth illustrates the role of fintech lending in helping MSMEs funding (Muchlis, 2018).

However, when compared to retail bank transactions in Indonesia, fintech is still considered to be much smaller. Based on data from Bank Indonesia, in 2016, the total value of cash withdrawal transactions, interbank transfers, and purchases with debit cards were IDR 5.623 trillion. For 2017, the total value was IDR 6,200 trillion, and in 2018 until November alone was IDR 5,781 trillion.

According to Demos (2016) and Hayashi (2016), fintech provides loans that are not too large in number, but access for users to get loans is easier because the use of new technology by fintech is user friendly and innovative. In addition, generally the minimum loan application and fintech lending tenure are also not as high as the minimum rate set by retail banks. For example, in Indonesia, fintech lending generally provides loan submission services with a minimum of varied submissions, ranging from IDR 100,000 to submissions of a maximum of IDR 50,000,000 - IDR 100,000,000, with a tenor of up to two years.

In addition, according to Bank Indonesia (2018), the total consumption loans channeled in 2018 by all banks in Indonesia amounted to IDR 1,436.8 trillion. For MSME loans channeled in 2016 is IDR 284.5 billion and rose to $800 \%$ or IDR 2.56 trillion (Gumiwang, 2018). It can be seen that fintech and retail banks still have a far position in terms of transactions. Many fintech users have started saving millions of money on their fintech accounts. However, retail bank customers save billions of money on their bank accounts.

Because of its relatively new nature, fintech in Indonesia currently operates only in big cities such as Jabodetabek, Surabaya, Bandung, Medan, Bali, and Malang. Unlike the case with retail banks, which have been already widely spread in Indonesia. For now, fintech is still very small in terms of market share and transactions when compared to retail banks. However, because fintech is not geographically concentrated, it is easier for fintech to expand its market share. Fintech's position on retail banks, both in terms of transactions, public trust, and money circulation, is still very far away. However, seeing the rapid growth of fintech, this can change over time and will be an opportunity for future researchers to study.

\section{Conclusion}

This study uses retail banks listed in the Indonesia Stock Exchange in 2016-2018 as samples. With purposive sampling technique, eight companies are obtained as research samples. Based on statistical testing with the model that has been done, it is found that there was no effect on fintech funding frequency on the stock returns of retail banks 
listed in the Indonesia Stock Exchange and that there is no effect on fintech funding value on the stock returns of retail banks listed in the Indonesia Stock Exchange.

This study has several limitations. First, the study uses fintech funding data to proxy the value of fintech companies due to the paucity of fintech data in Indonesia. Although there are reasonable assumptions made, this proxy can lead to bias result in the empirical analysis. Second, the sample period, 34 months from January 2016 to October 2018, might be too short to conclude the result for the panel study regressions. However, these are the only data available. Future researchers are expected to be able to widen the period of research and expand research samples for maximum results. Researchers in the future can also see the effect of the stages of fintech startup investment on future retail bank stock returns for stronger results.

\section{References}

Agustiyanti (2016). OJK Arranges Collaboration between Bank and Fintech. Berita Satu. Retrieved October 2018, from http://id.beritasatu.com/home/ojk-atur-kolaborasi-bank-danfintech/143123

Bahri, S. (2018). Bank Mandiri Teams Up with KoinWorks and Amartha for MSME Funding. KoinWorks. Retrieved October 2018, from https://koinworks.com/blog/kerjasama-bankmandiri/

Bank Indonesia. (2018). MSME Credit Report. Retrieved October 2018, from https://www.bi.go.id/id/umkm/kredit/laporan/ Default.aspx

Bank Indonesia. (2018). Statistics of Electronic Money Payment Systems. Retrieved October 2018, from https://www.bi.go. $\mathrm{id} / \mathrm{id} /$ statistik/sistem-pembayaran/uang-elektronik/contents/ transaksi.aspx

Capgemini., \& Efma. (2016). World retail banking report. Retrieved October 2018, from https://www.febelfin.be/sites/default/files/ InDepth/worldretailbankingreport2015.pdf

Chishti, S., \& Barberis, J. (2016). The Fintech Book: The Financial Technology Handbook for Investors, Entrepreneurs and Visionaries. Chichester, West Sussex: Wiley.

Chuen, K., Lee, D., \& Teo, E.G.S., (2015). Emergence of FinTech and the LASIC Principles. Journal of Financial Perspectives. EY Global FS Institute, 3(3), 24-36. https://doi.org/10.2139/ ssrn.2668049

Buckley, R., Arner, D., \& Barberis, J. (2016). The Evolution of Fintech: A New Post-Crisis Paradigm? Georgetown Journal of International Law, 47(4), 1271-1319. https://doi.org/12711319. 10.2139/ssrn.2676553.

Davila, A., Foster, G., \& Gupta, M. (2003). Venture capital financing and the growth of startup firms. Journal of Business Venturing, 18(6), 689-708. https://doi.org/10.1016/S08839026(02)00127-1
Dean, B., \& Giglierano, J. (1990) Multistage financing of technical start-up companies in Silicon Valley. Journal of Business Venturing, 5(6), 375-389. https://doi.org/10.1016/08839026(90)90012-I

Deloitte Center for Financial Industry. (2017). Fintech by the numbers. Retrieved November 2018, from: https://www2. deloitte.com/content/dam/Deloitte/ru/Documents/financialservices/fintech-by-the-numbers.pdf

Demos, T. (2016). Loans for Weddings: Fintech Learns to Focus. The Wall Street Journal. Retrieved October 2018, from https:// www.wsj.com/articles/new-fintech-lenders-narrow-theirscope-1461193681

EY. (2018). Global Banking Outlook 2018. Retrieved November 2018, from https:/www.ey.com/Publication/vwLUAssets/ ey-global-banking-outlook-2018/\$File/ey-global-bankingoutlook-2018.pdf

EY. (2018). ASEAN FinTech Cencus 2018. Retrieved November 2018, from https:/www.ey.com/en_sg/financial-services/ asean-fintech-census-2018

Ferrari, R. (2016). FinTech Impact on Retail Banking - From a Universal Banking Model to Banking Verticalization. In S. Chishti, \& J. Barberis, The Fintech Book: The Financial Technology Handbook for Investors, Entrepreneurs and Visionaries (p. 248-252). London: Wiley. https://doi. org/10.1002/9781119218906.ch65

Financial Stability Board. (2017). Financial Stability Implications for Fintech. Retrieved November 2018, from https://www.fsb. org/wp-content/uploads/R270617.pdf

Gumiwang, R. (2018). Fintech Lending, Pinjam Peminjam yang Makin Menjamur. Tirto.id. Retrieved September 2018, from https://tirto.id/fintech-lending-pinjam-meminjam-online-yangmakin-menjamur-cDpo

Hayashi, Y. (2016). Consumer Watchdog Chief Sees Role for Fintech in Payday Lending. The Wall Street Journal. Retrieved October 2018, from https://www.wsj.com/articles/consumer-watchdogchief-sees-role-for-fintech-in-payday-lending-1460061346

Huang, D. (2015). Banks and Fintech Firms' Relationship Status: It's Complicated. The Wall Street Journal. Retrieved October 2018, from http://www.wsj.com/articles/banks-and-fintechfirms-relationship-status-its-complicated-1447842603.

Juengerkes, B. E. (2016). FinTechs and Banks - Collaboration is Key. In S. Chishti, \& J. Barberis, The FinTech Book: The Financial Technology Handbook for Investors, Entrepreneurs and Visionaries (p. 179-182). London: Wiley.

Jun, J., \& Yeo, E. (2016). Entry of FinTech Firms and Competition in the Retail Payments Market. Asia-Pacific Journal of Financial Studies, 45(2), 159-184. https://doi.org/10.1111/ajfs.12126

KPMG (2017). Banking on the future. Retrieved September 2018, from https:/home.kpmg/content/dam/kpmg/au/pdf/2017/ banking-on-the-future-edition-3.pdf

KPMG. (2018). The Pulse of Fintech:Biannual global analysis of investment in fintech. Retrieved February 2019, from 
https:/home.kpmg/content/dam/kpmg/xx/pdf/2018/07/h12018-pulse-of-fintech.pdf

Laven, M., \& Bruggink, D. (2016). How FinTech is transforming the way money moves around the world: An interview with Mike Laven. Journal of Payments Strategy \& Systems. 10(1), 6-12.

Lee, I., \& Shin, Y. J. 2017. Fintech: Ecosystem, business models, investment decisions, and challenges. Kelley Business School, Indiana University. ScienceDirect, Elsevier. Business Horizon, 61(1), 35-46. https://doi.org/10.1016/j.bushor.2017.09.003

Li, Y., Spigt, R., \& Swinkels, L. (2017). The impact of Fintech startups on incumbent retail banks' share prices. Rotterdam: Erasmus University Rotterdam. Springer Link. Journal of Financial Innovation. 26(3), 1-16. https://doi.org/10.1186/ s40854-017-0076-7

Mbama, C. (2018). Digital banking, customer experience and bank financial performance: UK customers' perceptions. International Journal of Bank Marketing, 36(2), 230-255.

Miller, D., \& Liu, K. (2014). Creative Destruction: Evidence from Initial Public Offerings. Academy of Management Proceedings. https:// doi.org/10.5465/ambpp.2014.17308abstract

Mina, A., Lahr, H., \& Hughes, A. (2013). The demand and supply of external finance for innovative firms. Industrial and Corporate Change, 22(4), 869-901. https://doi.org/10.1093/icc/dtt020

Muchlis, A. C. (2018). BCA Distributes Rp. 25 Billion UMKM Credit Through Klik ACC. Kontan. Retrieved December 2018, from https://keuangan.kontan.co.id/news/bca-salurkan-kreditumkm-rp-25-miliar-lewat-klikacc.

Muradi. (2018). Injected Funding Fintech Lending Industry Increasingly Wriggling. Kontan. https://keuangan.kontan.co.id/ news/disuntik-pendanaan-industri-fintech-lending-semakinmenggeliat.

Navaretti, G., Calzolari, G., \& Pozzolo, A. (2017). Fintech and banking. Friends or Foes?. European Economy. Banks, Regulation, and The Real Sector. Retrieved October 2018, from http://european-economy.eu/wp-content/uploads/2018/01/ EE_2.2017-2.pdf

Omarini, A. (2015). Retail banking: business transformation and competitive strategies for the future. New York: Palgrave Macmillan.

Fintech Actors Grows 78\%. (2017). Kata Data. Retrieved September 2018, from https://databoks.katadata.co.id/ datapublish/2017/09/22/2015-2016-pelaku-fintech-indonesiatumbuh-78-persen.

Peters, G. W., \& Panayi, E. (2015). Understanding Modern Banking Ledgers through Blockchain Technologies: Future of Transaction Processing and Smart Contracts on the Internet of Money. Social Science Research. 239-279. Retrieved from https://arxiv.org/pdf/1511.05740.pdf

PwC. (2018). Digital Banking Survey 2018. Retrieved December 2018, from https://www.pwc.com/id/en/publications/assets/ financialservices/digital-banking-survey-2018-pwcid.pdf

PwC. (2016). Blurred lines: How FinTech is shaping Financial Services. Retrieved October 2018, https://www.pwc.com/il/en/ home/assets/pwc_fintech_global_report.pdf

Rahmah, S. (2018). Distributing UMKM Loans, BCA Partners with Fintech. Kompas. Retrieved October 2018, from https:// ekonomi.kompas.com/read/2018/01/15/130400226/salurkankredit-umkm-bca-gandeng-fintech.

Rita, E. (2018). Fintech Transaction Volume Continues to Increase. Berita Satu. Retrieved October 2018, from http://www. beritasatu.com/satu/492786-volume-transaksi-fintech-terusmeningkat.html.

Romānova, I., and Kudinska, M. (2016). Banking and Fintech: A Challenge or Opportunity?. In: Contemporary Issues in Finance: Current Challenges from Across Europe, 98, 21-35. Emerald Group Publishing. https://doi.org/10.1108/S1569375920160000098002

Sahi, H. (2017). Studying market reactions to Fintech companies - Acquisitions and initial public offerings in OECD Countries. Lappeenranta, Finland: Master Thesis, Lappeenranta University of Technology. Retrieved September 2018, from https://lutpub. lut.fi/bitstream/handle/10024/135181/Master's\%20Thesis\%20 Sahi\%20Heikki.pdf;jsessionid=6BFAFEE6E2AF62A9B9973 CF0B172E918? sequence $=2$

Sood, A., \& Tellis, G. (2009). Do Innovations Really Pay Off? Total Stock Market Returns to Innovation. Marketing Science, 28(3), 442-456. https://doi.org/10.1287/mksc.1080.0407

Sorkin, A.R. (2016). Fintech Firms Are Taking on the Big Banks, but Can They Win. The New York Times. Retrieved September 2018, from https://www.nytimes.com/2016/04/07/business/dealbook/ fintech-firms-are-taking-on-the-big-banks-but-can-they-win.html

Sorrentino, F. (2015). Millennials \& FinTech are top of mind for traditional banks. Forbes. Retrieved September 2018, from https://www.forbes.com/sites/franksorrentino/2015/11/20/ heard-at-the-2015-aba-national-convention/\#34e0886465cb

Wood, G., \& Buchanan, A. (2015). Advancing Egalitarianism. In: D.L.K. Chuen (ed.), Handbook of Digital Currency: Bitcoin, Innovation, Financial Instruments, and Big Data. London: Elsevier. 